\title{
BUKU PANDUAN WISATA BUDAYA KABUPATEN KLATEN
}

\section{${ }^{1}$ Eko Cahyo Kusumo Wibowo, ${ }^{2}$ Patra Aditia, ${ }^{3}$ Wirania Swasty}

\author{
Universitas Telkom, Program Studi Desain Komunikasi Visual \\ Jl. Telekomunikasi No. 1, Dayeuh Kolot, Jawa Barat \\ wirania@tcis.telkomuniversity.ac.id
}

\begin{abstract}
ABSTRAK
Klaten sebagai kabupaten sangat kaya potensi budaya. Potensi harus mampu membuat Klaten menjadi salah satu tujuan wisata budaya selain Solo dan Yogyakarta. Informasi tentang potensi pariwisata budaya kurang disajikan, sehingga banyak informasi menjadi kurang menarik bagi wisatawan. Hal ini tentu mempengaruhi penyebaran informasi ilmu pengetahuan dan potensi wisata baik warisan budaya maupun kerajinan. Selain itu, minat masyarakat tentang potensi budaya masih rendah dilihat dari wisatawan yang berkunjung ke wisata budaya. Tujuan utama dari penelitian ini adalah untuk merancang buku panduan wisata yang dapat meningkatkan daya tarik Klaten yang memiliki potensi budaya lokal yang lebih menarik bagi publik. Untuk mengatasi permasalahan di atas, penulis mengumpulkan data yang diperlukan dengan menggunakan metode observasi lapangan, studi literatur, dan wawancara terkait sumber. Setelah mengumpulkan data, penulis merancang buku panduan budaya dan media yang mendukung buku panduan mencakup peta wisata, belly binding, kartu pos, dan kemasan buku. Mudah-mudahan, hal ini akan dapat membantu Dinas Kebudayaan, Pemuda dan Olahraga Kabupaten Klaten dalam memperkuat citra pariwisata serta merancang media yang tepat untuk menyampaikan informasi untuk menarik kesadaran masyarakat terhadap keberadaan pariwisata budaya.
\end{abstract}

Kata kunci: Budaya, Klaten, Buku Panduan, Ilustrasi.

\begin{abstract}
Klaten as a regency is rich in cultural potential. The potential could turn the regency into one of cultural tourism destinations, besides Solo and Yogyakarta. The information on the cultural tourism potentials of the regency is not well presented so that it can not attract tourists. It certainly influences the dissemination of information on cultural knowledge and potentials either cultural heritage or craft work. Besides, public interest on the cultural potentials is still low considering the number of tourists visiting the cultural tourism. The main objective of this study is to combine a travel guide that can increase enthusiasm towards Klaten which has indigenous cultural potentials that can interest public more. As to solve the problems, the writer collected the required data by using field observation, literature study and interview related to the sources. After collecting data, the writer combined cultural manual as well as the media that can support the travel guide including tourism map, belly binding, post card and book cover. It is expected that it can support the Department of Tourism, Youth and Sports of Klaten Regency in strengthening its tourism image as well as creating appropriate media to deliver information which will in turn attract public awareness towards the existence of cultural tourism.
\end{abstract}

Keywords: Culture, Klaten, Travel Guide, Illustration. 


\section{PENDAHULUAN}

Indonesia merupakan negara yang unik dengan berbagai suku dan budaya dengan ciri khas masing-masing. Tanah Jawa menjadi salah satu pulau yang sangat kental akan berbagai tradisi dan kebudayaan di Indonesia. Kekayaan budaya yang dimiliki Tanah Jawa menyimpan berbagai macam sejarah dan ilmu pengetahuan. Kekayaan tersebut banyak dipengaruhi oleh kerajaankerajaan besar Jawa yang jangkauan kekuasaanya hingga ke luar Indonesia.

Kerajaan besar tersebut terbagi dalam beberapa periode kekuasaan yaitu Kerajaan Hindu/Budha, Kerajaan Islam hingga Kerajaan Jawa Moderen yang masih ada hingga saat ini. Adanya Keraton dari berbagai Kesultanan dan Kasunanan yang tersebar di tanah Jawa saat ini masih menjaga kelestarian budaya yang semakin hilang seiring dengan perkembangan jaman. Kerajaan-kerajaan tersebut juga sangat mempengaruhi kebudayaan di pulau Jawa yang sangat beragam, mulai dari rumah adat, upacara adat, barang peninggalan, kesenian, pakaian, makanan dan lain sebagainya. Luas wilayah dan banyaknya populasi suku Jawa memperngaruhi budaya yang dianutnya, budaya Jawa di bedakan menjadi 3 garis besar, yakni budaya Jawa Timur, Jawa Tengah - Daerah Istimewa Yogyakarta dan Banyumasan.

Adapun Kabupaten Klaten sendiri diapit oleh Kesunanan dan Kesultanan yang berada di tengah pusat kota budaya Solo dan Yogyakarta. Hal ini menjadikan Klaten sebagai sebuah kabupaten yang sangat kaya akan potensi budaya daerah. Berbagai peninggalan sejarah mulai dari tempat peninggalan nenek moyang yang berupa candi-candi, tempat ziarah religi, desa wisata, seni pertunjukan hingga upacara tradisi yang sangat kental akan sarat budaya daerah di Kabupaten Klaten.

Kabupaten Klaten yang menyimpan banyak potensi budaya daerah seharusnya dapat menjadi destinasi wisata budaya selain Solo dan Yogyakarta. Namun, penyampaian informasi mengenai potensi tersebut kurang dapat dikemas dengan lebih maksimal, sehingga banyak informasi mengenai potensi wisata budaya yang disampaikan menjadi kurang diminati oleh wisatawan. Berdasarkan hal di atas, maka disimpulkan inti permasalahan yang dihadapi sebagai berikut: (a) Penyampaian informasi mengenai potensi wisata budaya yang tersebar di Kabupaten Klaten belum dikemas dengan maksimal. (b) Ketertarikan masyarakat akan potensi budaya daerah dirasakan masih rendah.

Dalam hal ini, visual dan desain sangat berpengaruh besar dalam kemudahan penyampaian informasi yang dapat menarik perhatian lebih, karena secara tidak sadar manusia akan lebih tertarik dengan hal yang berhubungan dengan visual daripada yang hanya berupa tulisan. Untuk itu penggunaan visual dan desain akan sangat membantu dalam penyampaian informasi sehingga akan menarik lebih banyak wisatawan dan objek wisata budaya menjadi semakin diminati.

Adapun permasalahan yang dihadapi adalah bagaimana merancang sebuah media informasi berupa Buku Panduan Wisata Budaya Kabupaten Klaten yang lebih menarik perhatian masyarakat? Dengan demikian, tujuan diadakannya studi ini adalah merancang sebuah buku panduan wisata budaya yang dapat memunculkan ciri khas Klaten agar lebih menarik sehingga potensi budaya daerah lebih diminati oleh 
masyarakat. Perancangan media yang digunakan yaitu dalam bentuk buku panduan wisata budaya Kabupaten Klaten yang berjudul "Buku Panduan Wisata Budaya Kabupaten Klaten".

\section{KAJIAN TEORI}

\subsection{Teori kebudayaan}

Secara etimologis, kebudayaan berasal dari kata buddhayah (Sansekerta) yang berarti budi; akal kebudayaan memiliki nilai-nilai universal. Sedangkan semesta budaya dunia dibedakan menjadi tujuh jenis, yaitu: mata pencaharian, peralatan, sistem kemasyarakatan, bahasa, kesenian, sistem pengetahuan dan religi.

Kebudayaan Indonesia didefinisikan sebagai keseluruhan aktivitas yang dilakukan oleh bangsa Indonesia yang lebih dikenal dengan sebutan budaya nusantara, tersebar dari Sabang hingga Merauke, dari Pulau Miangas hingga Pulau Rote. Secara historis dapat dikenali melalui berbagai hasil peninggalan masa lampau, khususnya melalui puncak-puncak kebudayaan, sebagai hasil peradaban baik tertulis maupun tersirat seperti: candi Borobudur dan Mendut, Monumen Nasional dan Taman Mini Indonesia Indah, legenda Sang Kuriang dan Malin Kundang, Bumi Manusia dan Saman, tradisi dan adat-istiadat, karya seni, dan sebagainya.

Secara sinkronis dapat dikenali melalui berbagai hasil cipta, rasa, dan karsa yang terjadi saat ini. Dari segi asal-usul kebudayaan ada dua macam, kebudayaan asli dan kebudayaan asing. Kebudayaan asli diwariskan melalu nenek moyang, sedangkan kebudayaan asing diperoleh melalui hubungan dengan luar negeri, seperti: India, Arab, dan dunia Barat.

\subsection{Teori pariwisata}

The International Association of Scientific Expert in Tourism (AIEST) mendefinisikan pariwisata merupakan keseluruhan dari keterkaitan dan fenomena yang dihasilkan dari orang yang bepergian dan berhenti di tempat tempat yang bukan merupakan tempat domisili secara terus menerus atau tempat kerja, baik untuk liburan maupun dalam konteks kegiatan usaha atau studi. Pariwisata ditempatkan dalam konteks keseluruhan rekreasi, mempertahankan kebutuhan akan perjalanan keluar dari tempat kerja biasanya, dan berfokus untuk alasan perjalanan. Pariwisata merupakan proses, kegiatan, dan hasil yang timbul dari hubungan dan interaksi di kalangan wisatawan, pemasok pariwisata, pemerintahan, warga sekitar, dan lingkungan sekitarnya yang terlibat dalam menarik dan menerima pengunjung.

Dalam era global dewasa ini, pariwisata hendaknya lebih dipersepsikan sebagai wahana untuk meningkatkan kualitas hubungan antar manusia, sehingga terjalin saling pengertian menghormati/ menghargai, mempererat persahabatan, dan meningkatkan solidaritas sosial. Pariwisata pun ditujukan untuk meningkatkan kualitas hidup masyarakat, khususnya penduduk setempat serta lingkungan hidup: lingkungan fisik/alam, lingkungan budaya.

Dalam mempromosikan pariwisata terdapat berbagai macam cara yang bisa dilakukan, terdapat beberapa cara yang dapat membuat sebuah pariwisata menjadi dikenal oleh para wisatawan seperti memproduksi artikel yang dicetak, menjadikan pariwisata sebagai berita utama, melalui media iklan, publikasi dan 
dengan media elektronik yang sangat penting dan berkaitan dengan bisnis pariwisata. Hal vital lain yang dapat diproduksi untuk mempromosikan pariwisata yaitu referensi manual, trafik, buku panduan, peta, jadwal perjalanan, dan buku yang dapat berasal dari media internet maupun media cetak.

\subsection{Teori buku dan teknologi grafika}

Buku adalah kumpulan lembaran kertas berisi tulisan atau gambar yang disatukan dan dijilid pada salah satu sisinya. Buku adalah media massa pertama yang dalam banyak hal menjadi media paling personal; memberikan informasi, sekaligus menghibur. Buku Panduan wisata termasuk dalam Trade Book, yang dapat berupa hardcover atau softcover serta berbentuk buku panduan.

Grafika adalah suatu cara atau teknik penyampaian informasi, pesan, pikiran, gagasan, perasaan melalui penggandaan dengan cara dicetak dan disajikan kepada khalayak. Banyak hasil karya manusia diwujudkan melalui teknologi grafika mulai dari koran, majalah, surat kabar, buku rapor, buku pelajaran, bungkus korek api, ijazah, sertifikat, perangko, spanduk, tiket, materai, uang kertas, kemasan hingga poster dan bentuk cetakan ukuran besar lainnya.

Kertas merupakan bahan yang sangat penting dalam pekerjaan cetak sehingga penyesuaian kualitas dari kertas akan sangat dominan di dalam menentukan kualitas cetak. Jenis kertas terbagi menjadi tiga yaitu: Pertama, berdasarkan jenis serat; Kertas mengandung kayu (contohnya Koran, HHI) dan kertas bebas kayu (contoh HVS, HVO). Kedua, berdasarkan pekerjaan terakhir, yaitu kertas coated dengan permukaannya halus dan mengkilap (contoh art paper) dan kertas uncoated yang mana permu-kaan kertas kasar dan daya serap terhadap minyak kuat (contoh koran, HHI, HVS). Ketiga, berdasarkan penggunaanya, yaitu kertas cetak (HVO, koran, art paper); kertas tulis (HVS, kertas gambar); kertas bungkus (kertas sampul, kertas Samson); serta kertas khusus (kertas uang, kertas sigaret, kertas tissue).

\subsection{Teori desain komunikasi visual}

Desain komunikasi visual mempelajari konsep komunikasi dan ungkapan daya kreatif, yang diaplikasikan dalam berbagai media komunikasi visual dengan mengolah elemen desain grafis yang terdiri atas gambar (ilustrasi), huruf dan tipografi, warna, komposisi, dan layout. Semua itu dilakukan guna menyampaikan pesan secara visual, audio, dan/atau audio visual kepada target sasaran.

\section{a). Layout dan grid}

Layout merupakan susunan teks, gambar dan elemen visual lainnya dalam desain yang menyerupai hasil tampilan akhir. Sebuah layout biasanya dibuat dengan struktur, seperti grid. Sebuah halaman layout memiliki area aktif dan pasif yang mengacu pada cara baca mata pada halaman. Adapun grid merupakan struktur grafis yang digunakan untuk mengatur penempatan elemen individu dalam desain atau halaman. Sebuah grid berfungsi sebagai panduan untuk posisi teks, gambar, diagram, grafik, folio, straplines, kolom dan elemen desain lainnya. Terdapat dua tipe grid utama yang dapat dijadikan acuan:

Pertama; grid Asimetris dimana kedua halaman menggunakan sistem yang sama, yang berarti satu halaman merupakan 
salinan halaman yang lain. Grid ini mungkin akan berat sebelah daripada sisi halaman lainnya (biasanya kiri), yang dibuat dengan menggunakan kolom sempit di sisinya untuk keterangan, catatan, ikon atau unsur lainnya. Hal ini memberikan kesempatan untuk menambahkan elemen kreatif tertentu sambil mempertahankan konsistensi desain secara keseluruhan.

Kedua, grid simetris yang mana sisi bagian kiri merupakan cerminan dari sisi kanan. Hal ini memberikan tampilan margin dalam dan luar yang sama. Keserdehanaan tata letak dan halaman menciptakan hubungan jarak yang mengatur keseimbangan antar teks.

\section{b). Teori ilustrasi}

Inti dari ilustrasi yaitu memikirkan ide dan konsep yang berasal dari dasar tentang gambaran apa yang akan dicoba untuk dikomunikasikan. Dijabarkan pula ilustrasi bahwa gambar ilustrasi dapat memecahkan masalah pada suatu pokok permasalahan melalui ide dan fikiran kreatif; berfungsi untuk lebih menarik perhatian audience serta memberikan gambaran tentang suatu hal yang ada di dalam teks.

Pemilihan media dan penggunaan material dalam ilustrasi merupakan hal penting yang dapat membangkitkan ide dengan kiasan visual. Media yang digunakan dalam membuat ilustrasi terbagi menjadi: fotografi, tradisional/ manual, digital dan mixing media.

Terdapat banyak teknik pewarnaan dalam gambar yang semua teknik tersebut dapat dipakai untuk mengaplikasikan ide desain ilustrasi dengan cepat, tergantung seberapa banyak informasi dan detail karakter yang dibutuhkan. Beberapa yang sering dipakai yaitu: Pertama, teknik warna pada fotokopi hitam-putih atau laser print. Kedua, teknik warna retro merupa-kan teknik pewarnaan yang cepat dan efektif karena bekerja dengan cara men-jiplak gambar menggunakan kertas putih dan milar.

Ketiga, sketsa/ kombinasi foto yang mana foto digital dicetak, lalu konsep ide digambar pada kertas kalkir yang ditaruh di atas cetakan foto tadi, selanjutnya dipindai dan diwarnai pada program Photoshop. Selanjutnya, Hand Drawing/ Digital Color menggunakan pensil atau spidol lalu dipindai dan diwarnai masih menggunakan Photoshop. Terakhir, hybrid color drawing; gambar dibuat dengan menggunakan pensil pada kertas kalkir lalu dipindai dan diberi warna dasar; selanjutnya dicetak dan ditambahkan detail dengan menggunakan marker dan pensil warna dan dipindai lagi untuk diberi pengaturan warna dan final touch.

\section{c). Teori tipografi}

Tipografi merupakan representasi visual dari sebuah bentuk komunikasi verbal dan merupakan properti kandungan nilai fungsional dan nilai estetikanya, huruf memiliki potensi untuk menerjemahkan atmosfir-atmosfir yang tersirat dalam sebuah abstraksi bentuk bentuk visual. Tipografi adalah seni memilih dan menata huruf untuk berbagai kepentingan menyampaikan informasi berbentuk pesan sosial ataupun komersial.

Dijelaskan pula bahwa dalam perkembangannya, ada lebih dari seribu macam huruf Romawi atau Latin yang diakui tetapi sejatinya merupakan hasil perkawinan silang dari jenis huruf berikut ini: 
(a) Huruf Romein yang garis hurufnya memperlihatkan perbedaan antara tebaltipis dan mempunyai kaki atau kait yang lancip pada setiap batang hurufnya. (b) Huruf Egyptian dimana garis hurufnya memiliki ukuran yang sama tebal pada setiap sisinya. Kaki atau kaitnya berbentuk lurus atau kaku. (c) Huruf Miscellaneous yang mementingkan nilai hiasnya daripada nilai komunikasinya. Bentuknya senantiasa mengedepankan aspek dekoratif dan ornamental. (d) Huruf Script yang menyerupai tulisan tangan dan bersifat spontan

Adapun tipografi dibagi berdasarkan karakteristik yang melekat pada bagian anatomi bentuk huruf dan berdasarkan bagian tubuh.

Tabel 1. Pembagian tipografi berdasarkan anatomi bentuk tubuh

\begin{tabular}{|l|l|}
\hline Roman & $\begin{array}{l}\text { Bentuk dasar dari tipografi } \\
\text { roman, ditemukan di monument } \\
\text { Roman. }\end{array}$ \\
\hline Italic & $\begin{array}{l}\text { Tipografi yang ditarik dari poros } \\
\text { siku. Biasanya dirancang untuk } \\
\text { tipografi serif. }\end{array}$ \\
\hline Condensed & $\begin{array}{l}\text { Lebih sempit dari versi Roman } \\
\text { dan berguna di ruang terbatas. }\end{array}$ \\
\hline Extended & $\begin{array}{l}\text { Lebih lebar dari versi Roman. } \\
\text { Sering digunakan dalam judul } \\
\text { untuk mengisi ruang kosong. }\end{array}$ \\
\hline Boldface & $\begin{array}{l}\text { Mengacu pada tipografi dengan } \\
\text { goresan tebal yang lebih luas dari } \\
\text { versi Roman. }\end{array}$ \\
\hline Light or Thin & Versi tipis dari versi Roman. \\
\hline
\end{tabular}

(Sumber: Ambrose dan Harris, 2009.)

Tabel 2. Pembagian tipografi berdasarkan bagian tubuh

\begin{tabular}{|c|c|}
\hline & $\begin{array}{l}\text { Old Style } \\
\text { gaya tulisan yang memiliki hiasan } \\
\text { selama abad pertengahan. Juga dikenal } \\
\text { sebagai Block, Gothic, Old English, Black } \\
\text { dan Broken. }\end{array}$ \\
\hline
\end{tabular}

\begin{tabular}{|c|c|}
\hline & $\begin{array}{l}\text { Blackletter } \\
\text { Font Romawi yang memiliki goresan } \\
\text { ringan yang kontras dan teknik } \\
\text { penekanan miring. }\end{array}$ \\
\hline & $\begin{array}{l}\text { Italic } \\
\text { Berdasarkan tulisan tangan Italia } \\
\text { periode Renaissance dimana bentuk } \\
\text { surat ringkas. }\end{array}$ \\
\hline & $\begin{array}{l}\text { Script } \\
\text { mempreproduksi bentuk ukiran } \\
\text { kaligrafi }\end{array}$ \\
\hline & $\begin{array}{l}\text { Transitional } \\
\text { Tipografi transisi dari bentuk Old Style } \\
\text { ke modern; ditandai dengan } \\
\text { peningkatan kontras goresan dan } \\
\text { goresan kaki vertical yang lebih kuat. }\end{array}$ \\
\hline & $\begin{array}{l}\text { Modern } \\
\text { Tipografi dari abad pertengahan XVII } \\
\text { yang ditandai dengan kontras goresan } \\
\text { yang ekstrim.. }\end{array}$ \\
\hline & $\begin{array}{l}\text { Square serif } \\
\text { memiliki variasi penekanan goresan } \\
\text { yang sedikit dan tebal, serif persegi. }\end{array}$ \\
\hline & $\begin{array}{l}\text { Sans serif } \\
\text { Tipografi tanpa kaki dan sedikit variasi } \\
\text { penekanan pada goresannya yang } \\
\text { pertama kali diperkenalkan oleh } \\
\text { William Caslon pada 1816. }\end{array}$ \\
\hline & $\begin{array}{l}\text { Serif/Sans serif } \\
\text { Sebuah perkembangan baru yang } \\
\text { meliputi kedua serif dan abjad sans serif. }\end{array}$ \\
\hline
\end{tabular}

(Sumber: Ambrose dan Harris, 2009.)

\section{d). Teori Warna}

Warna dapat memberi desain lebih hidup, membantu untuk membangun hirarki, menggarisbawahi informasi penting, dan menambah emosi pada desain. Reproduksi warna berasal dari prinsip dasar penglihatan tiga warna pada mata manusia. Mata mengandung tiga tipe reseptor yang sensitif terhadap tiap warna utama yaitu merah, hijau dan biru. Warna tersebut disebut dengan warna additive karena ketika semua warna tersebut dicampur maka akan menghasilkan warna putih. Sedangkan standard warna yang digunakan dalam proses pewarnaan memakai tinta cyan, magenta, kuning, dan hitam, dan ketika warna tersebut dicampur dengan warna disampingnya akan menghasilkan warna yang lain. 
Red, Green, Blue (RGB) merupakan warna aditif yang digunakan gambar pada layar komputer. Warna RGB yang digunakan komputer memproduksi sekitar 70 persen spektrum warna yang dapat diterima oleh mata manusia. Cyan, Magenta, Yellow, Black (CMYK) merupakan warna subtraktif yang digunakan dalam empat warna proses cetak. Gambar komputer dalam warna RGB akan dipindah ke dalam warna CMYK ketika akan dicetak.

\section{METODOLOGI}

Guna memperoleh data penelitian yang dibutuhkan, penyusun menggunakan beberapa metode. Yang pertama adalah studi Pustaka berupa metode yang digunakan untuk pengumpulan data melalui tempat penyimpanan hasil penelitian, yaitu perpustakaan. Studi pustaka dilakukan dengan mengkaji teori terkait penelitian meliputi teori wisata, buku serta elemen desain.

Metode pengumpulan data selanjutnya adalah pengamatan/ observasi. Semua penelitian dunia sosial pada dasarnya menggunakan teknik observasi. Faktor terpenting dalam teknik observasi adalah observer (pengamat) dan orang yang diamati yang kemudian juga berfungsi sebagai pemberi informasi, yaitu informan. Observasi dilakukan pada objek wisata budaya, baik lokasi, benda, serta pengunjung wisatawan yang ada di Kabupaten Klaten.

Terakhir, metode pengumpulan data menggunakan metode wawancara: caracara memperoleh data dengan berhadapan langsung, bercakap-cakap, baik antara individu dengan individu maupun individu dengan kelompok. Wawancara dilakukan kepada pihak Dinas Kebudayaan Pariwisata
Pemuda dan Olahraga Kabupaten Klaten bagian Pariwisata serta bagian Kebudayaan, ahli terkait Balai Pelestarian Cagar Budaya Jawa Tengah bagian dokumentasi dan publikasi, pemilik atau seseorang yang terkait langsung dengan budaya daerah, serta wisatawan yang sedang berkunjung.

Adapun metode pengolahan data, dilakukan dengan membuat matriks perbandingan yang memunculkan dua dimensi yang berbeda, konsep atau seperangkat informasi; untuk mengidentifikasikan perbedaan dan persamaan dalam data penelitian. Matriks ini membantu mengidentifikasi bentuk penyajian dengan lebih seimbang, yang biasanya merupakan hambatan peng-analisis dalam memberi perhatian terhadap data yang sebanding.

Pengolahan data dilakukan dengan menganalisa produk terdahulu dan produk sejenis (DK Eyewitness Travel Guides, Panduan Wisata Jawa Tengah, 100 Countries 5000 Ideas) untuk memudahkan Penulis dalam melakukan analisis.

\section{DISKUSI}

\subsection{Analisis data}

Berdasarkan hasil wawancara yang telah dilakukan kepada narasumber, didapat kesimpulan sebagai berikut: Pertama, kondisi pariwisata di Klaten saat ini masih perlu adanya perbaikan dan pengembangan lebih lanjut. Beberapa objek wisata yang ada belum ditata dan dikembangkan dengan baik. Dinas Kebudayaan, Pemuda dan Olahraga terus berupaya untuk mengadakan pembenahan dan perbaikan, agar destinasi wisata di Klaten dapat menarik perhatian wisatawan baik domestik maupun mancanegara untuk berkunjung di Klaten. 
Selain itu, Klaten memiliki banyak potensi wisata, terutama wisata yang berhubungan dengan budaya karena Klaten diapit oleh dua kota besar Keraton Yogyakarta dan Solo. Ciri khas yang telah dikenal luas, diantaranya Kain Lurik khas Klaten yang dibuat dengan Alat Tenun Bukan Mesin (ATBM) dan gerabah putaran miring yang hanya terdapat di desa Melikan, alat tersebut tidak terdapat di daerah lain.

Adapun kesadaran masyarakat klaten untuk mendukung keberhasilan pembangunan pariwisata di klaten sangat dibutuhkan karena pada prinsipnya tujuan akhir dari pembangunan pariwisata adalah kemakmuran masyarakat klaten. Untuk itu diharapkan dengan adanya perancangan buku panduan wisata budaya dapat membantu dinas tersebut dalam mengangkat dan mengembangkan potensi wisata yang ada di Kabupaten Klaten agar dapat menarik perhatian wisatawan baik domestik maupun manca untuk berkunjung di Klaten.

Generasi muda berperan penting dalam melestarikan dan mengembangkan budaya daerah sendiri, namun yang paling ditakutkan dari generasi muda saat ini adalah mereka mulai meninggalkan budaya daerah sendiri dan pergi bekerja dan tinggal di kota. Untuk itu agar dapat menarik perhatian generasi muda yaitu dengan meramu budaya tersebut dengan visual yang merangsang imajinasi mereka, karena generasi muda terutama anak SMP dan SMA masih memiliki imajinasi yang tinggi. Dengan demikian, wisatawan juga memerlukan buku panduan wisata agar dapat mengetahui lebih detail dan menambah wawasan, karena visual/informasi yang diberikan dalam bentuk papan informasi maupun brosur sangatlah terbatas.
Buku panduan yang berjudul "Klaten tourism guide" diterbitkan oleh Dinas Kebudayaan Pariwisata, Pemuda, dan Olah raga Kabupaten Klaten berisi mengenai potensi wisata yang ada di Klaten. Pada bagian cover belakang terdapat peta wisata yang dapat dijadikan petunjuk mengenai letak objek wisata. Isi buku terbagi menjadi lima bagian yaitu objek \& daya tarik wisata alam, objek \& daya tarik wisata budaya, perayaan tradisional, wisata buatan dan seni kerajinan. Setiap bagian wisata terdapat gambar berupa foto objek dan informasi singkat mengenai objek wisata. Dan pada halaman terakhir terdapat data pendukung wisata berupa daftar hotel, rumah makan dan biro perjalanan wisata yang terdapat di Klaten.

Selain buku Panduan Wisata yang telah diterbitkan oleh dinas tersebut, juga terdapat buku yang memberikan informasi berupa buku saku yang menjelaskan Cagar Budaya Candi Sojiwan dan Plaosan. Buku tersebut berisi informasi mengenai Candi dan dilengkapi beberapa foto.

Melalui analisis berupa matriks perbandingan dengan proyek sejenis, dapat ditarik kesimpulan sebagai acuan dalam perancangan buku, antara lain: untuk memudahkan audiens ketika akan membawa dan membaca, ukuran buku panduan wisata tidak lebih dari A5 (14.8 x $21 \mathrm{~cm}$ ). Adapun jumlah halaman sebaiknya sekitar 50 halaman karena konten hanya berisi mengenai wisata budaya yang ada di Klaten, serta untuk pemberian informasi secara maksimal. Adapun target sasaran yaitu masyarakat Klaten dan wisatawan domestik. Untuk itu bahasa yang akan digunakan adalah bahasa Indonesia.

Penulisan buku panduan sebaiknya menggunakan deskripsi singkat mengenai 
objek wisata yang akan dilengkapi dengan catatan perjalanan, tips dan saran mengenai objek wisata.

Proses penjilidan buku panduan atau teknik Binding yang akan digunakan yaitu Singer stitch. Sementara teknik Grid yang digunakan yaitu mengkombinasikan Grid Simetris dan Grid Asimetri, dengan menggunakan sistem 1 dan 2 kolom pada setiap halaman.

Konten buku banyak menggunakan elemen infografis sebagai media penyampaian informasi, dan infografis akan digunakan dalam pembuatan peta wilayah, peta wisata, denah arsitektur, dan informasi lain yang berhubungan dengan objek wisata. Adapun ilustrasi menggunakan teknik digital dalam pembuatan sketsa dan dalam pewarnaan agar dapat mempercepat proses. Foto ditambahkan sebagai pelengkap visual mengenai kondisi asli objek wisata.

Melalui matriks perbandingan dapat disimpulkan font yang tepat digunakan dalam perancangan buku panduan wisata yaitu dengan menggunakan kombinasi antara Sans Serif dan Serif. Warna halaman menggunakan warna putih, dan beberapa halaman disesuaikan dengan tema wisata. Warna pada layout menggunakan warna warna yang cerah agar dapat lebih menarik perhatian.

Konten utama yang ada yaitu petunjuk penggunaan buku, pengenalan wilayah terkait objek wisata, deskripsi objek wisata dan apa saja yang menarik. Informasi pendukung yang dapat dimasukkan yaitu catatan perjalanan, rute transportasi, tempat menginap, tempat makan dan minum, dan beberapa informasi yang berhubungan dengan objek wisata.

\subsection{Konsep perancangan}

\subsubsection{Konsep Pesan}

Perancangan buku dimaksudkan untuk menginformasikan keberadaan, keunikan dan potensi budaya daerah yang ada di Kabupaten Klaten sebagai kota budaya, sejarah dan kerajinan. Strategi yang dilakukan yaitu dengan menanamkan image mengenai apa yang sudah menjadi ciri khas dan dimiliki oleh Klaten, sehingga masyarakat menjadi tahu akan kekayaan budaya yang dimiliki Kabupaten Klaten.

Selain itu, buku ini dimaksudkan mengajak target audiens untuk datang berkunjung serta berwisata ke objek wisata budaya daerah sehingga akan menaikkan pendapatan daerah Kabupaten Klaten. Strategi dilakukan dengan meramu budaya daerah menggunakan ilustrasi dalam buku yang dapat dijadikan panduan wisata budaya.

Komunikasi disesuaikan dengan data khalayak sasaran yang telah diperoleh dari hasil pengumpulan data. Target audiens adalah wisatawan baik yang berasal dari dalam maupun luar daerah Kabupaten Klaten yang berjenis kelamin pria dan wanita dengan kisaran umur mulai dari 16 tahun hingga 50 tahun. Berasal dari kalangan menengah hingga menengah atas yang berprofesi sebagai pelajar, mahasiswa dan masyarakat umum. Selain itu mereka memiliki perhatian terhadap benda-benda cagar budaya, serta yang suka berwisata dan berpetualang.

Konsep komunikasi yang digunakan menggunakan Bahasa Indonesia yang menjelaskan informasi dan beberapa istilah bahasa daerah yang mampu menarik perhatian sasaran agar pesan yang ingin 
disampaikan dapat dimengerti dan menarik perhatian khalayak sasaran baik secara verbal maupun nonverbal.

\subsubsection{Konsep Kreatif}

Dalam perancangan ini digunakan media dan unsur unsur daerah yang menjadi ciri khas yang bisa dibanggakan oleh masyarakat Klaten. Ilustrasi dan infografis akan menjadi unsur utama yang mendukung penyampaian informasi. Dengan demikian diharap memudahkan penyerapan informasi oleh masyarakat terhadap budaya daerah. Adapun unsur budaya daerah yang mempengaruhi dalam perancangan adalah kain lurik dan candi.

Kain Lurik menjadi ciri khas yang telah dikenal luas di sekitar daerah Kabupaten Klaten, sehingga digunakan sebagai pengingat dan penanda bahwa buku panduan wisata tersebut berasal dari Klaten. Elemen kain lurik yang berupa garis akan menjadi elemen pada layout dan penanda pada halaman buku.

Adapun unsur yang terdapat pada Candi maupun bangunan Cagar Budaya dapat menjadi elemen pendukung kuat sebagai konsep desain. Unsur ini dapat menjadi referensi dalam menentukan elemen layout, infografis dan pemilihan warna yang sesuai. Bentuk candi merak digunakan sebagai bentuk dasar dari paragraph yang menjelaskan objek wisata. Dan masing-masing objek wisata akan dilengkapi dengan ilustrasi yang mewakili objek yang terkandung dalam teks.

\subsubsection{Konsep Visual}

Penggunaan ilustrasi dan infografis merupakan unsur utama yang digunakan. Dalam pembuatan ilustrasi menggunakan media digital dengan menggabungkan efek tradisional sebagai sketsa dan pewarnaannya, sehingga hasil ilustrasi akan memberikan efek tradisional. Hal ini dikarenakan informasi yang ingin disampaikan berhubungan dengan budaya daerah yang kuat dengan nuansa tradisional. Foto juga digunakan sebagai pendukung dan pemberi image keadaan objek wisata yang sebenarnya serta memberikan gambaran mengenai bagian detail bangunan cagar budaya.

Unsur utama yang terdapat pada Layout adalah Ilustrasi, sehingga kombinasi Grid Simetris dan Asimetris digunakan untuk menjaga kesinambungan tampilan agar dapat melengkapi satu sama lain. Pada paragraf yang memberikan penjelasan rincian mengenai informasi wisata, akan digunakan sistem kombinasi 1 dan 2 kolom dalam satu halaman untuk memudahkan audiens menyerap dan memahami informasi yang diberikan serta menjadi lebih fokus.

Adapun warna-warna yang digunakan dalam perancangan ini adalah warna-warna tradisional yang menggambarkan nuansa tradisi budaya daerah. Pengambilan sampling warna menggunakan warnawarna yang terdapat pada tone foto objek wisata dengan sedikit pengaturan contrast dan color balance. Teknik ini biasa digunakan oleh digital artist ketika akan membuat suatu concept art scene yang membutuhkan referensi warna yang berasal dari alam. Pemilihan warna yang soft dimaksudkan untuk menjaga keseimbangan antara warna dalam ilustrasi dengan warna layout. Karena ilustrasi merupakan unsur penting yang mampu menarik perhatian pembaca, sehingga warna yang digunakan untuk layout menyesuaikan dengan warna yang digunakan dalam ilustrasi. Warna yang terdapat dalam ilustrasi menyesuaikan 
dengan warna asli foto referensi dengan sedikit pengaturan contrass \& color balance.

Tipografi menggunakan dua jenis font yang berbeda; Norpeth dan PT Sans Caption. Norpeth memiliki banyak jenis tipe font, namun yang digunakan dalam perancangan tugas akhir ini hanya empat yaitu light, bold, italic, dan bold. Font ini merupakan font Sans Serif yang baik jika dikombinasikan dengan ilustrasi. Font ini digunakan untuk menjelaskan informasi mengenai objek wisata. PT Sans Caption memiliki ketegasan yang dapat dijadikan headline dan subheadline. Penggunaan font ini dipilih untuk menjaga kesinambungan dengan ilustrasi maupun foto yang banyak menggunakan elemen garis.

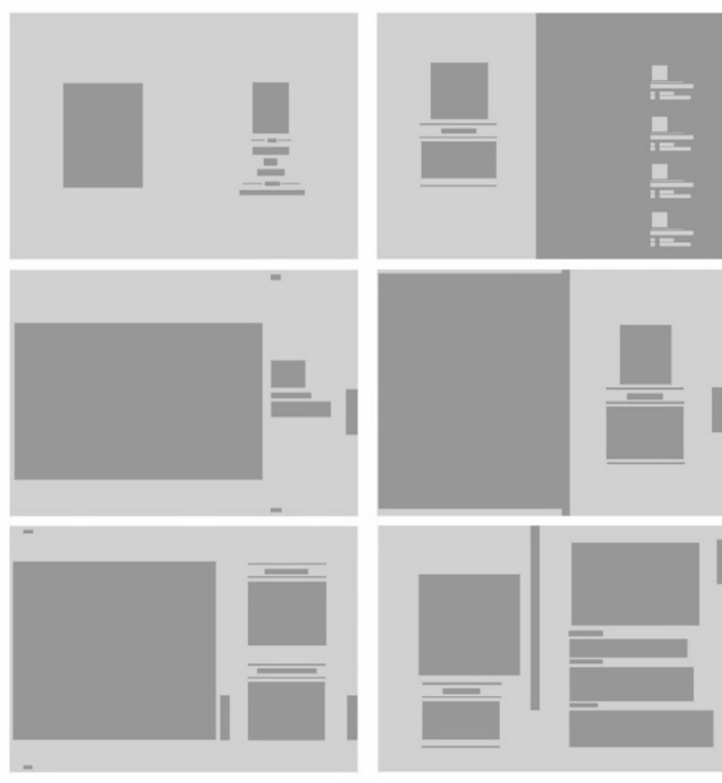

Gambar 1. Konsep Layout Sumber : Dokumentasi Pribadi

\subsubsection{Konsep media}

Agar penyampaian informasi mengenai potensi budaya daerah sebagai wisata dapat dilakukan secara maksimal maka dibutuhkan media yang mampu memuat banyak informasi. Selain itu juga dibutuhkan sebuah media yang dapat meramu budaya daerah menjadi bentuk visual yang mampu merangsang imajinasi masyarakat agar menjadi tertarik dan aware terhadap budaya daerah. Buku dapat memberikan informasi sekaligus menghibur, selain itu buku merupakan tempat pengumpul masa lalu, serta agen pengembangan personal dan perubahan sosial.

Buku ini menggunakan elemen yang terdapat pada kain lurik. Kain lurik dipilih karena merupakan budaya daerah yang telah menjadi ciri khas sejak dulu, hal ini diperkuat dengan didirikannya replika Alat Tenun Bukan Mesin (ATBM) yang kini menjadi ikon Klaten. Kertas yang akan digunakan sebagai bahan isi buku yaitu Matte Paper 120 gram, pemilihan kertas ini berdasarkan hasil observasi pada buku panduan wisata yang menjadi referensi penulis dengan bertanya langsung kepada Percetakan Bandung. Kertas tersebut tidak mengkilap seperti Art Paper, sehingga ilustrasi yang ada dalam buku akan terlihat bagus dan jelas.

Teknik Binding yang digunakan yaitu Pamphlet-stich binding. Penggunaan teknik ini merupakan bentuk dasar teknik penyatuan pada buku, yaitu dengan menjahit kertas pada bagian punggung dengan menggunakan benang. Aplikasi yang simpel memberikan keleluasaan kertas pada setiap halaman untuk bergerak, sehingga ilustrasi yang ditampilkan dapat terlihat secara maksimal. Selain itu dengan teknik ini buku akan lebih mudah untuk dibawa bersama wisatawan untuk berpergian. Pada bagian cover akan diberikan selembar kertas tambahan disekeliling cover sebagai penambah nilai desain dan juga sebagai aplikasi dari motif kain lurik. 


\subsection{Hasil perancangan}

Pada cover terdapat dua buah ilustrasi, cover depan terdapat ilustrasi Alat Tenun Bukan Mesin (ATBM) yang telah menjadi ciri khas Kabupaten Klaten yang dikenal luas. Tujuannya sebagai pengingat dan memperkuat image yang dimiliki Klaten pada buku panduan wisata budaya. Susunan tipografi pada judul buku menggunakan konsep susunan pada bangunan candi, yang terdapat di Klaten. Selain itu ilustrasi cagar budaya juga digunakan pada cover belakang dan halaman pemisah cover dan isi. Pada halaman tersebut terdapat tagline pariwisata Kabupaten Klaten yaitu The Shine of Java. Penggunaan tagline pada halaman dimaksudkan untuk memberikan gambaran bahwa Klaten merupakan cahaya Jawa yang memiliki beragam budaya yang merupakan perpaduan dari dua kota budaya Yogyakarta dan Surakarta.

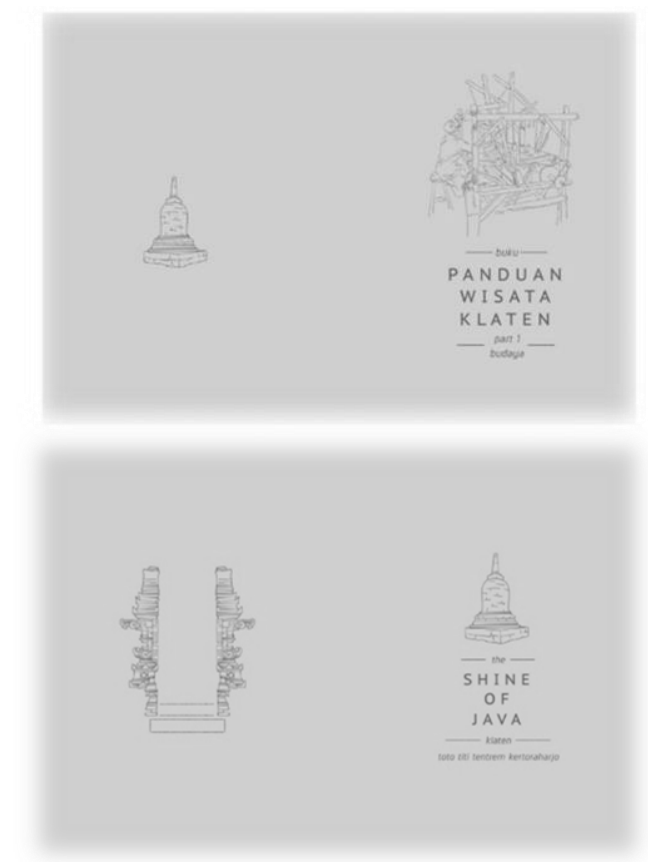

Gambar 2. Cover dan Halaman depan Buku Panduan Sumber : Dokumentasi Pribadi

Penggunaan ilustrasi pada peta dimaksudkan agar lebih mempermudah penyampaian informasi mengenai wisata budaya yang berada pada masing-masing wilayah di Kabupaten Klaten. Ilustrasi juga digunakan untuk meng-gambarkan beberapa suasana objek wisata serta lebih membangkitkan daya tarik audiens terhadap informasi yang disampaikan. Ilustrasi juga digunakan untuk membuat denah cagar budaya yang mempermudah pembaca dalam mengamati struktur bangunan candi. Fotografi juga digunakan untuk mendukung gambaran nyata mengenai objek wisata.

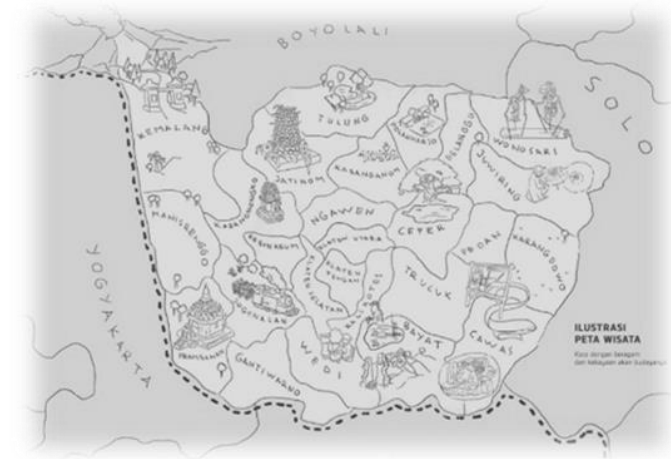

Gambar 3. Ilustrasi Peta Wisata Kabupaten Klaten Sumber : Dokumentasi Pribadi

Berikut beberapa tampilan halaman yang merupakan hasil perancangan yang terdapat dalam buku. Dalam gambar di bawah ini terlihat penerapan konsep visual yang mencakup gaya ilustrasi, penerapan layout dan grid serta tipografi.

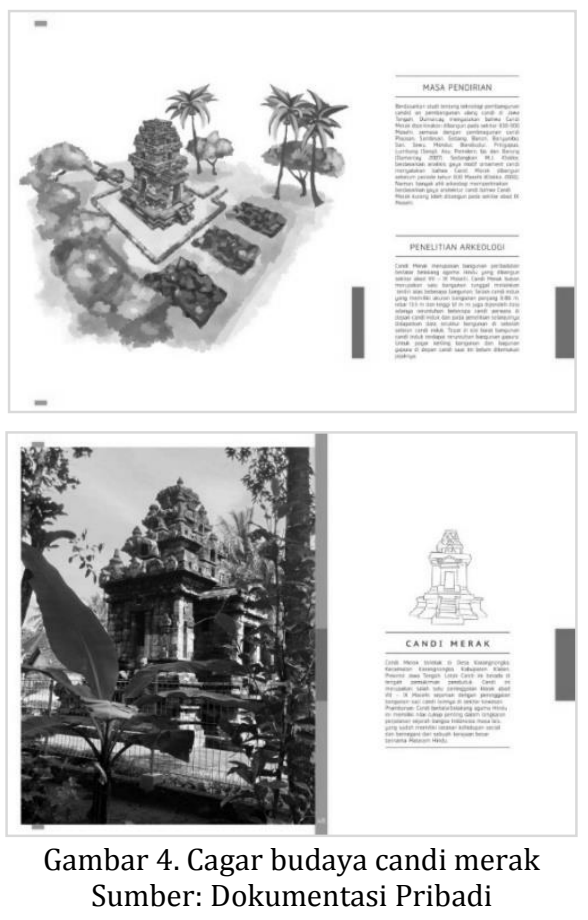



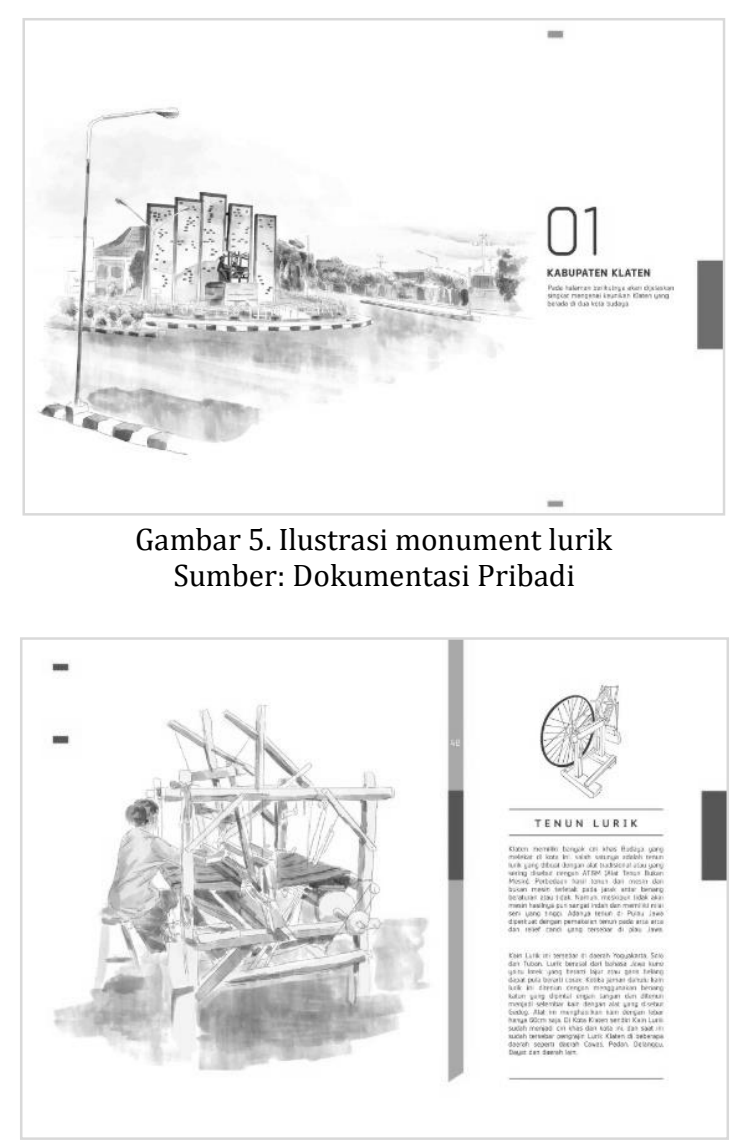

Gambar 6. Ilustrasi Tenun Lurik ATBM Sumber: Dokumentasi Pribadi

Sebagaimana telah disebutkan dalam konsep, buku ini memakai pula Belly Binding atau bisa juga disebut pita kertas yang mengelilingi buku. Selain berfungsi sebagai penjelas singkat mengenai buku, belly binding juga dapat berguna sebagai pembatas buku.

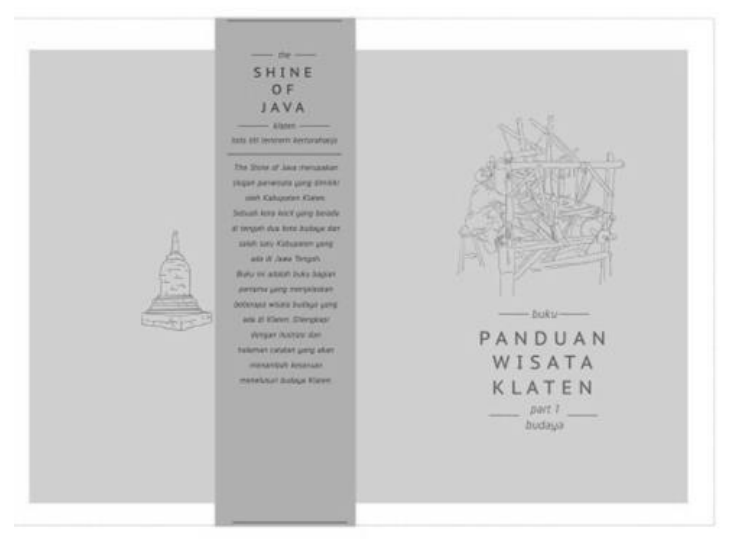

Gambar 7. Belly Binding Sumber: Dokumentasi Pribadi

\section{SIMPULAN}

Berdasarkan hasil pengamatan dan perancangan yang telah dilakukan, terdapat beberapa hal yang dapat disimpulkan terkait objek penelitian, yakni penggunaan ilustrasi pada buku panduan wisata budaya menjadikannya memiliki daya tarik yang lebih besar. Hal tersebut dikarenakan masih belum banyak buku panduan wisata terutama yang berada di Indonesia yang menggunakan ilustrasi sebagai unsur utama.

Selain itu, buku panduan wisata yang telah ada sebelumnya terlihat belum dikemas secara maksimal dan kurang memperlihatkan ciri khas yang ada di Kabupaten Klaten. Hal tersebut tentunya berpengaruh pada awareness masyarakat mengenai potensi yang dimiliki. Dengan demikian, diharapkan dengan perancangan buku panduan wisata budaya yang telah dilakukan, potensi wisata Kabupaten Klaten menjadi lebih dikenal serta diminati oleh masyarakat dan wisatawan.

Melengkapi dan menyempurnakan penelitian dan perancangan ini, ada baiknya membuat program atau buku lanjutan atau serial mengenai potensi wisata lainnya di kabupaten Klaten dengan sistematika perancangan yang senada sehingga potensi yang lainnya dapat lebih terangkat. Saran lainnya adalah melakukan kerja sama dengan pihak-pihak yang berhubungan langsung dengan objek wisata seperti Kelompok Sadar Wisata, Pecinta Cagar Budaya serta biro perjalanan yang dapat menjadi ujung tombak mempromosikan dan memperluas penyebaran informasi yang akurat mengenai potensi wisata yang ada di Kabupaten Klaten. 


\section{DAFTAR PUSTAKA}

[1] Zeegan, Lawrence dan Crush. 2005. The Fundamentals of Illustration. 10th ed. Switzerland: AVA Publishing SA.Al-Quran.

[2] Koentjaraningrat (1974) dalam Ratna, Nyoman Kutha. 2010. Metodologi Penelitian Kajian Budaya dan Ilmu Sosial Humaniora pada Umumnya. Cetakan Pertama. Pustaka Pelajar: Yogyakarta.

[3] Vanhove, Norbert. 2005. The Economics of Tourism Destinations. 1st ed. Elsevier Butterworth-Heinemann. Burlington.

[4] Goeldner, Charles R dan Ritchie, J.R.Brent. 2009. Tourism Principles, Practices, Philosophies. 11th ed. John Wiley \& Sons, Inc. : New Jersey.

[5] Sedarmayanti. 2014. Membangun \& Mengembangkan Kebudayaan \& Industri Pariwisata. Cetakan pertama. Refika Aditama: Bandung.

[6] Baran, Stanley J. 2012. Pengantar Komunikasi Massa. Vol. 1. Edisi 5. Penerbit Erlangga: Jakarta.

[7] Wasono, Antonius Bowo dkk. 2008. Teknik Grafika dan Industri Grafika. Jilid 1. Jakarta: Direktorat Pembinaan Sekolah Menengah Kejuruan, Direktorat Jenderal Manajemen Pendidikan Dasar dan Menengah, Departemen Pendidikan Nasional.

[8] Dameria (2005) dalam Wasono, Antonius Bowo dkk. 2008. Teknik Grafika dan Industri Grafika. Jilid 1. Jakarta: Direktorat Pembinaan Sekolah Menengah Kejuruan, Direktorat Jenderal Manajemen Pendidikan Dasar dan Menengah, Departemen Pendidikan Nasional.

[9] Ambrose, Gavin dan Harris, Paul. 2009. The Fundamental of Graphic Design. 10th ed. AVA Publishing SA: Switzerland.

[10] Doyle, Michael E. 2007. Color Drawing. 10th ed. John Wiley \& Sons, Inc. : New Jersey.

[11] Sihombing, Danton. 2003. Tipografi dalam Desain Grafis. Cetakan kedua. PT. Gramedia Pustaka Utama : Jakarta.

[12] Tinarbuko, Sumbo. 2009. Semiotika Komunikasi Visual. Cetakan ketiga. Jalasutra : Yogyakarta.

[13] Ratna, Nyoman Kutha. 2010. Metodologi Penelitian Kajian Budaya dan Ilmu Sosial Humaniora Pada Umumnya. Cetakan Pertama. Pustaka Pelajar : Yogyakarta.

[14] Menurut Adler dan Adler (2009) dalam Ratna, Nyoman Kutha. 2010. Metodologi Penelitian Kajian Budaya dan Ilmu Sosial Humaniora Pada Umumnya. Cetakan Pertama. Pustaka Pelajar : Yogyakarta.

[15] Rohendi, Tjetjep. 2011. Metodologi Penelitian Seni. CV Cipta Prima Nusantara: Semarang. 